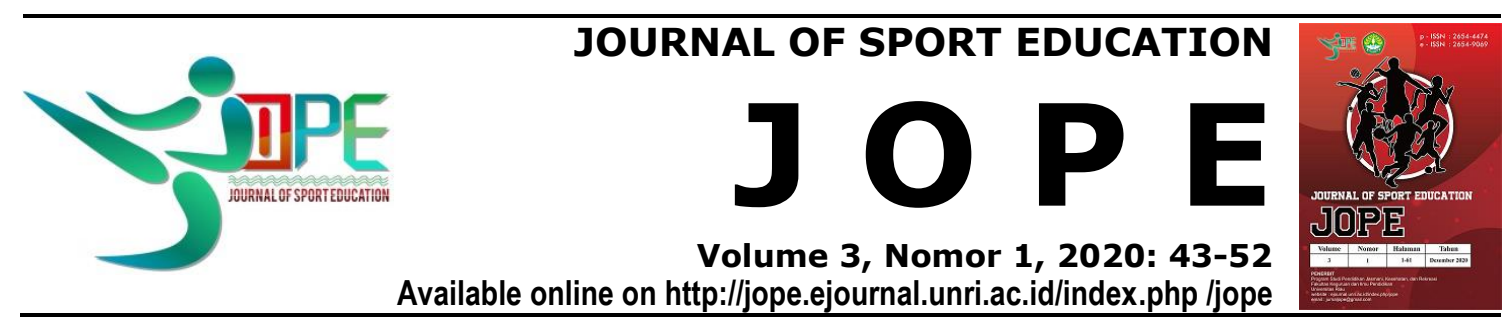

\title{
Metode bantuan tentor: Penerapannya dalam meningkatkan passing atas bola voli mini siswa kelas $v$ sekolah dasar
}

\author{
Yusuf Utama \\ Sekolah Dasar Negeri 83 Pekanbaru \\ yu.yusufutama@gmail.com
}

Received: 01 November 2020; Revised 03 November 2020; Accepted 24 November 2020

doi) http://dx.doi.org/10.31258/jope.2.2.43-52

\begin{abstract}
Abstrak
Tujuan penelitian ini adalah untuk meningkatkan hasil belajar passing atas bola voli mini melalui bantuan tutor sebaya siswa kelas $\mathrm{v}$ sekolah dasar. Metode penelitian yang digunakan adalah penelitian tindakan kelas. Teknik dan instrumen pengumpulan data menggunakan observasi, kuesioner, dan tes tertulis. Analisis data dilakukan secara deskriptif komparatif yang bertujuan untuk membandingkan kondisi sebelum dan sesudah diadakan tindakan perbaikan pembelajaran. Tahapan analisis melalui reduksi data, penyajian data,dan penarikan kesimpulan. Subjek yang digunakan berjumlah 40 siswa. Hasil penelitian menunjukkan bahwa pada pratindakan dari 40 siswa, terdapat 18 siswa $(45 \%)$ yang tuntas belajar. Pada akhir siklus I dari 40 siswa, terdapat 20 siswa (50\%) yang tuntas belajar. Pada akhir siklus II dari 40 siswa, 32 siswa $(82,87 \%)$ telah tuntas belajar. Berdasarkan hasil penelitian tersebut dapat disimpulkan metode bantuan tutor sebaya dapat meningkatkan hasil belajar passing atas bola voli mini siswa kelas V Sekolah Dasar.
\end{abstract}

Kata Kunci: hasil belajar, passing atas, Bola Voli, Tutor Teman Sebaya

\section{The tentor assistance method: Its application in improving passing over mini volleyball for fifth grade elementary school students}

\begin{abstract}
The purpose of this study is an effort to improve the results of learning to pass over mini volleyball through the help of peer tutors for grade V elementary school students. The research method used is classroom action research. The data analyzed included quantitative data (by presenting numbers as a measure of achievement), and qualitative data (presenting numbers as a comparison). Data analysis was carried out in a descriptive comparative manner which aims to compare the conditions before and after the learning corrective action was taken. The stages in the action of analyzing data include data reduction, data presentation, and drawing conclusions. The subjects used were 40 students. The results showed that in the pre-action of 40 students, there were 18 students (45\%) who had finished learning. At the end of the first cycle of 40 students, there were 20 students (50\%) who had finished learning. At the end of the second cycle of 40 students, 32 students (82.87\%) have finished learning. Thus it can be concluded that the application of the peer tutor assistance method can improve the learning outcomes of passing on mini volleyball for fifth grade elementary school students.
\end{abstract}

Keywords: learning outcomes, top passing, volleyball, peer tutoring 
How To Cite: Utama, Y. (2020). Metode bantuan tentor: Penerapannya dalam meningkatkan passing atas bola voli mini siswa kelas v sekolah dasar. Journal of Sport Education (JOPE), 3 (1), 43-52.

\section{PENDAHULUAN}

Bola voli merupakan cabang olahraga permainan yang telah dikenal masyarakat mulai dari usia anak-anak hingga usia dewasa baik dari yang berjenis kelamin pria ataupun wanita (Supriyanto \& Martiani, 2019). Bolavoli menjadi olahraga yang digemari masyarakat karena permainannya yang menyenangkan (Hartanti \& Hidayat, 2016). Apabila melihat kurikulum yang ada di dunia pendidikan Indonesia saat ini, permainan bola voli sudah diajarkan mulai dari tingkat Sekolah Dasar, Sekolah Menengah Pertama maupun Sekolah Menengah Atas (Hidayat \& Iskandar, 2019). Dalam proses pembelajaran bola voli di sekolah aspek kognitif, afektif dan psikomotor sasaran utama keberhasilan siswa dalam proses pembelajaran di sekolah. Hal ini dapat diperkuat dengan banyaknya usaha para peneliti dalam rangka meningkatkan aspek-aspek tersebut melalui berbagai metode. Salah satu penelitian dalam pendidikan jasmani yang melibatkan 3 aspek tersebut sebagai patokan keberhasilan pembelajaran adalah penelitian yang dilakukan oleh (Allo et al., 2020) dengan judul Meningkatkan Kemampuan Hasil Belajar Lempar Lembing Dengan Menggunakan Media Turbo.

Secara lebih mendalam, penelitian tersebut menggunakan 3 aspek (kognitif, afekti dan psikomotor) untuk menentukan keberhasilan dari proses pembelajaran. Untuk dapat mencapai keberhasilan pembelajaran tentu tidaklah mudah. Perlu kreativitas guru untuk dapat merealisasikan hal tersebut. Banyak hal yang perlu diperhatikan oleh seorang guru agar pembelajaran dapat terlaksana dengan baik. Salah satu hal yang perlu di cermati adalah terkait dengan motivasi siswa. Dengan adanya motivasi tentu punya peluang yang tiggi bagi siswa untuk berhasil mengikuti pembelajaran dengan baik. Hal ini senada dengan apa yang disampaikan (Fadlih \& Riyanto, 2019) bahwa kegiatan yang akan atau sementara dilakukan akan mengundang rasa gembira, gairah yang tinggi atau dengan hasrat yang besar akan sesuatu itu maka berpeluang untuk mendapatkan hasil yang cukup terbuka lebar. Melihat permainan bola voli banyak diminati oleh masyarakat mulai dari usia anak-anak hingga usia dewasa baik dari yang berjenis kelamin laki-laki maupun perempuan, hal ini bertolak belakang dengan permsalahan yang terjadi di SD Negeri 83 Pekanbaru. Pada saat proses pembelajaran, masih banyak ditemukan masalah Siswa kelas $\mathrm{V}$ dalam melakukan passing atas karena merasa takut terhadap bola. Siswa juga beranggapan bahwa bola itu berat dan siswa ragu jika jari yang dimiliki akan mengalami cedera dikarenakan menahan bola yang datang. Selain itu, siswa juga tidak berani melihat arah datangnya bola ketika melakukan passing atas. Penggunaan metode pembelajaran yang kurang menyenangkan menyebabkan siswa kurang termotivasi Berdasarkan hasil evaluasi, sebanyak $42 \%$ siswa yang telah dapat melakukan teknik passing atas dengan baik dan benar dan sisanya 58\% masih belum. Hal tersebut tentu 
ada permasalahan yang perlu segera diberikan solusi yang tepat.Aoabula peulis tilik lebih lajut, beberapa kemungkinan yang menjadi penyebab hal tersebut adalah motivasi siswa dalam mengikuti pembelajaran kurang. Selain itu kemungkinan lain adalah karena minimnya kemampuan dan keberanian seorang siswa dalam melakukan teknik passing atas. Selain itu, beberapa kemungkinan lain yang dapat terjadi diantaranya adalah penerapan metode belajar yang belum sesuai oleh guru. Selain itu saat kegiatan pembelajaran siswa belum dilibatkan sepenuhnya. Ada banyak metode pembelajaran yang biasa digunakan untuk memberikan peluang tingkat keberhasilan pembelajaran di sekolah. Salah satunya adalah tutor sebaya. Tutor sebaya dinyatakan telah terbukti menjadi strategi efektif dalam pembelajaran. Efektif karena mampu mengembangkan interaksi dan keterampilan sosial, motivasi dan pengembangan diri. (Haris, 2018).

Berdasarkan permasalahan tersebut, maka peneliti bermaksud menggunakan metode tutor sebaya dalam pembelajaran bola voli mini untuk membantu siswa kelas V SD Negeri 83 Pekanbaru dalam rangka melakukan passing atas dengan baik. Selama ini metode tutor sebaya belum pernah digunakan dalam pembelajaran Bola voli mini di SD Negeri 83 Pekanbaru. Oleh karena itu pada artikel ini, peneliti ingin mengetahui Penggunaan metode bantuan tentor dalam rangka meningkatkan passing atas bola voli mini kelas v siswa Sekolah Dasar Negeri 83 Pekanbaru

\section{METODE}

Metode yang digunakan dalam penelitian ini adalah penelitian tindakan. Variabel yang digunakan peneliti terdiri dari dari dua variabel yaitu 1 variabel independen dan 1 variabel dependen. Menurut (Sugiyono, 2019), Penelitian tindakan yang menggunakan dua variabel, 1 independen (tindakan) dan 1 variabel dependen (hasil) termasuk ke dalam jenis penelitian tindakan sederhana. Subjek yang digunakan dalam penelitian adalah siswa siswa kelas v Sekolah Dasar Negeri 83 Pekanbaru yang berjumlah 40 orang.

Pengumpulan data dalam penelitian ini dilakukan melalui pengamatan, hasil tes siswa dan angket. Angket yang diberikan kepada siswa dilaksanakan pada siklus terakhir. setelah dilakukan tindakan.

Data yang dianalisis dalam penelitin ini adalah data kuantitatif data kualitatif. Analisis data dalam penelitian ini dilakukan secara deskriptif komparatif. Tujuan analisis ini digunakan untuk membandingkan kondisi sebelum dan sesudah tindakan. Tahapan tindakan dalam proses menganalisa data yaitu: reduksi data, penyajian data,dan penarikan kesimpulan.

\section{Reduksi Data}

Proses reduksi data dimaksudkan untuk pemilihan dan penyederhanaan data penelitian. Data-data yang relevan dengan penelitian selanjutnua diorganisasikan agar terbentuk sekumpulan data yang dapat memberi informasi yang benar.

\section{Penyajian data}

Adapun terkait dengan penyajian, perlu 
dilakukan analisis data yang meliputi:

a. Analisis hasil belajar pada siklus I dan II.

b. Keaktifan siswa dianalisis saat pembelajaran berlangsung.

c. Analisis kemampuan guru saat pembelajaran berlangsung.

d. Analisis penggunaan metode bantuan ketika pembelajaran berlangsung.

e. Membandingkan hasil sebelum tindakan nilai KKM.

f. Analisis RPP.

\section{Penarikan kesimpulan}

Penarikan kesimpulan disusun dengan mempertimbangkan secara evaluatif berdasarkan kegiatan-kegiatan yang ditempuh dalam dua tahap sebelumnya.

Secara terperinci prosedur penelitian tindakan kelas ini dijabarkan sebagai berikut:

1. Rancangan Siklus 1

a. Perencanaan

Beberapa hal yang perlu dilakukan sebelum pelaksanaan tindakan yaitu:1) Penyusunan Rencana Pelaksanaan Pembelajaran (RPP); 2) Penyusunan lembar observasi; 3) Mempersiapkan peralatan dan beberapa bahan yang diperlukan dalam proses pembelajaran; 4) Pemilihan tutor dengen ketentuan: siswa memiliki kemampuan akademik yang bagus, memiliki kemampuan pengetahuan, pemahaman dan analisa yang baik serta dapat merespon permasalahan, memberikan bimbingan dan adaptasi dalam satu kelompok yang diberikan bimbingan; 5) penyusunan instrumen untuk mengevaluasi seberapa jauh penguasaan siswa terhadap kompetensi dasar yang dipelajari.

b. Tindakan
Tindakan yang dilaksanakan menyesuaikan dengan skenario pembelajaran yang telah dirancang, yaitu, 1) Pemberian angket oleh guru dalam rangka untuk mengetahui sejauh mana penguasaan passing atas sebelum menggunakan metode tutur sebaya; 2) Penyampaian oleh pengajar terkait dengan tujuan yang ingin dicapai dalam pembelajaran; 3) Peserta didik dibantu oleh guru dalam mempersiapkan peralatan dan beberapa bahan yang dibutuhkan dalam kegiatan pembelajaran; 4) Pemanasan diberikan oleh guru sebelum proses tindakan. Setelah pemanasan selesai, siswa diminta unutk berbaris dan membentuk kelompok dengan jumlah perkelompok 8-9 anak dengan tambahan 1 anak yang sudah bisa melakukan gerakan passing atas. Anak tersebut bertindak sebagai tutor dalam kelompoknya; 5) Penghargaan diberikan kepada anak yang mampu melakukan gerakan passing atas dengan baik dan benar.

\section{c. Observasi}

Observasi dilakukan untuk melihat keberhasilan anak dalam melakukan gerakan passing atas sehingga kompetensi dasar dapat tercapai dengan baik.

d. Refleksi

Penilaian terhadap tindakan yang sudah dilakukan apakah muncul permasalahan. Apabila permasalahan muncul dalam proses tindakan maka perlu dilakukan evaluasi.

2. Rancangan Siklus II

a. Perencanaan

Pelaksanaan skiklus II berdasarkan hasil refleksi sikul I.

b. Tindakan 
Siklus II, setiap kelompok ada 2 anak yang menjadi tutor sebaya. Pada siklus II lebih ditekankan pada fungsi sebenarnya, siswa yang menjadi tutor diberi materi tersendiri yaitu dengan memberikan pemantapan materi. Selanjutnya diberikan pula cara atau tehnik penyampaian materi pada temannya dan diberikan tanggung jawab penuh selama kegiatan pokok berlangsung. Pada kegiatan ini secara tidak langsung akan membuat tutor menjadi termotivasi dan merasa mendapatkan apresiasi. Hal ini membantu memperkuat apa yang telah dipelajari dan diperolehnya atas tanggung jawab yang dibebankan kepadanya. Ketika peserta didik belajar dengan tutor sebaya, peserta didik diharapkan juga mampu dalam mengembangkan kemampuan yang lebih baik.

c. Observasi

Kegiatan observasi siklus II sama dengan kegiatan observasi pada siklus I.

d. Refleksi

Refleksi pada siklus II berfungsi untuk membandingkan hasil siklus I dengan siklus II. Tindakan yang dilakukan apakah dapat meningkatkan passing atas atau tidak. Jika tidak terhadi peningkatan siklus perlu diulang kembaliAkan tetapi jika terjadi peningkatan maka siklus dihentikan.

\section{HASIL DAN PEMBAHASAN}

\section{Hasil}

\section{Pratindakan}

1. Siswa kelas VC SD Negeri 83 Pekanbaru berjumlah 40 siswa. Siswa tersebut terbagi menjadi 15 siswa putra dan 25 siswa putri.
Berdasarkan hasil survey tentang kegiatan pembelajaran materi passing atas bola voli mini didapatkan informasi bahwa pembelajaran yang dilaksanakan kurang berhasil.

2. Penggunaan metode pembelajaran yan tidak tepat menyebabkan siswa kurang fokus mengikuti pembelajaran.

3. Berdasarkan hasil wawancara yang sudah dilakukan diapatkan informasi bahwa siswa kesulitan dan kurang tertarik dalam menerima materi pembelajaran. Siswa terlihat tidak memperhatikan dan sibuk sendiri dan bahkan sibuk dengan teman lainnya ketika kegiatan pembelajaran berlangsung. Selain itu, sebagian siswa juga terlihat takut dan merasa canggung saat proses pembelajaran berlangsung.

4. Hasil observasi pada kegiatan pratindakan pembelajaran passing atas bola voli mini siswa kelas V SD Negeri 83 Pekanbaru masih rendah, hanya (45\%) yang telah mampu melakukan passing atas dengan benar. Atas dasar observasi tersebut maka perlu disusun sebuah tindakan untuk meningkatkan hasil belajar passing atas bola voli mini siswa kelas V SD Negeri 83 Pekanbaru dengan menggunakan metode bantuan tutor sebaya. Pelaksanaan tindakan dilakukan dengan 2 siklus. Masing-masing siklus terdiri dari 4 tahapan. Tahapan tersebut meliputi tahap perencanaan, tahap pelaksanaan tindakan, tahap observasi, dan tahap refleksi.

\section{Siklus 1}

Hasil pada siklus I tersebut dapat dilihat pada tabel 1 berikut ini: 
Tabel 1. Deskripsi Data Hasil Belajar Siklus I

\begin{tabular}{|c|c|c|}
\hline No Kriteria & Jumlah Anak & Prosentase \\
\hline 1. Tuntas & 20 & $50 \%$ \\
\hline 2. $\quad$ Belum tuntas & 20 & $50 \%$ \\
\hline Jumlah & 40 & $100 \%$ \\
\hline
\end{tabular}

Berdasarkan hasil deskripsi data siklus I, sisanya 20 siswa (50\%) belum mencapai hasil belajar passing atas bola voli mini KKM.

siswa kelas VC SD Negeri 83 adalah sebanyak 20 siswa $(50 \%)$ telah mencapai kriteria ketuntasan minimal (KKM) dan

\section{Siklus II}

Adapun hasil pada siklus II dapat dilihat pada tabel 2 beikut ini:

Tabel 2. Deskripsi Data Hasil Belajar Siklus II

\begin{tabular}{llll}
\hline No & Kriteria & Jumlah Anak & Prosentase \\
\hline 1. & Tuntas & 32 & $82,87 \%$ \\
\hline 2. & Belum tuntas & 8 & $17,23 \%$ \\
\hline Jumlah & 40 & $100 \%$ \\
\hline
\end{tabular}

Berdasarkan hasil deskripsi data siklus II, hasil belajar passing atas bola voli mini siswa kelas VC SD Negeri 83 adalah sebanyak 32 siswa $(82,87 \%)$ telah mencapai nilai KKM dan 8 siswa $(17,23 \%)$ belum mencapai nilai KKM.

\section{Perbandingan Hasil Tindakan Antar Siklus} Pelaksanaan tindakan perbaikan dari berikut:

Tabel 3. Perbandingan Hasil Belajar Pratindakan, Siklus I, dan Siklus II

\begin{tabular}{lllll}
\hline No & Kriteria & Pratindakan & Siklus I & Siklus II \\
\hline 1. & Tuntas & $45 \%$ & $50 \%$ & $82,87 \%$ \\
\hline 2. & Belum tuntas & $55 \%$ & $50 \%$ & $17,23 \%$ \\
\hline Jumlah & $\mathbf{1 0 0 \%}$ & $\mathbf{1 0 0 \%}$ & $\mathbf{1 0 0 \%}$ \\
\hline
\end{tabular}

Perbandingan hasil belajar passing atas bola voli mini siswa antar siklus yaitu dari pratindakan diperoleh 18 siswa (45\%) telah tuntas dan 22 siswa (55\%) belum mencapai ketuntasan. Setelah dilakukan tindakan siklus I, 20 siswa (50\%) telah mencapai ketuntasan belajar dan 20 siswa (50\%) belum tuntas pratindakan, siklus I, dan siklus II melalui metode bantuan tutor sebaya diketahui dari masing-masing tindakan mengalami peningkatan hasil belajar passing atas bola voli mini siswa kelas VC SD Negeri 83 Tahun Pelajaran 2018/2019. Perbandingan hasil yang diperoleh selama proses tindakan dijabarkan dalam bentuk tabel sebagai 
Tabel 4. Perbandingan Ketuntasan Belajar Pratindakan, Siklus I, dan Siklus II

\begin{tabular}{lllll}
\hline \multirow{2}{*}{ No } & \multirow{2}{*}{ Uraian } & \multicolumn{3}{c}{ Persentase } \\
\cline { 3 - 5 } & Pratindakan & Siklus I & Siklus II \\
\hline 1. & Tuntas & 18 & 20 & 32 \\
\hline 2. & Persentase Ketuntasan & $45 \%$ & $50 \%$ & $82,87 \%$ \\
\hline 3. & Tidak Tuntas & 22 & 20 & 8 \\
\hline 4. & Persentase Ketidaktuntasan & $55 \%$ & $50 \%$ & $17,23 \%$ \\
\hline Jumlah & $100 \%$ & $100 \%$ & $100 \%$ \\
\hline
\end{tabular}

Pada pratindakan diperoleh hasil ketuntasan yang kurang, yaitu hanya 18 siswa yang mencapai nilai KKM, sedangkan 22 siswa belum. Pada siklus I meningkat menjadi 20 siswa telah mencapai ketuntasan minimal, sedangkan 20 siswa masih belum mencapai ketuntasan minimal. Pada akhir tindakan siklus II tingkat ketuntasan belajar meningkat menjadi 32 anak telah tuntas belajar dan 8 siswa belum tuntas belajar. Pada pratindakan diperoleh nilai rata-rata hasil belajar siswa $45 \%$, pada siklus I mengalami peningkatan menjadi 50\%, dan pada akhir siklus II meningkat menjadi $82,87 \%$.

\section{Pembahasan}

Penelitian sebelumnya tentan metode tutor sebaya pernah dilakukan dan mendapatkan hasil yang sama. Beberapa penelitian tersebut dapat dilihat pada penelitian (Patamani, 2018) yang menghasilkan temuan bahwa metode tutor sebaya dapat meningkatkan hasil passing atas bola mini. Temuan lain juga didapatkan oleh (Hendriawan \& Indahwati, 2019) bahwa metode tutor sebaya dapat meingkatkan hasil belajar passing atas bola voli. Keberhasilan tersebut dalam dilihat dari peningkatan aspek pengetahuan sebesar $14,22 \%$ dan peningkatan pada aspek keterampilan sebesar $16,44 \%$. Tidak sampai disitu saja, penelitian yang serupa oleh (Nadhiroh \& Hidayat, 2017) juga mendapatkan temuan pada terjadi peningkatan pada aspek pengetahuan dan keterampilan belajar passing atas bola voli mini. Hanya saja pada penelitian tersebut tidak pada permaianan bola voli lapangan besar. Penelitian ini sebenarnya juga hampir mirip dengan penelitian yang dilakukan (Maulina, 2018) dan (Dadi, 2020). Hasil penelitiannya pun serupa bahwa memang tutor sebaya dapat meningkatkan hasil belajar passing atas bola voli mini.

Beberapa penelitian tersebut mendukung hasil penelitian yang sudah dilakukan peneliti. Berdasarkan hasil penelitian yang sudah dilakukan, perbaikan pembelajaran melalui penelitian tindakan kelas tentang passing atas bola voli mini melalui metode bantuan tutor sebaya dapat meningkatkan keaktifan dan semangat belajar siswa sehingga tujuan perbaikan tercapai dengan optimal. Penggunaan metode bantuan tutor sebaya terbukti sangat membantu peningkatan hasil belajar siswa hal ini dikarenakan kelebihan penggunaan metode tutor sebaya banyak memberikan keuntungan di antaranya siswa yang takut atau segan dengan guru menjadi tidak takut karena 
belajar dengan teman sebaya. Kelebihan lain model tutor sebaya yaitu peserta didik diajar untuk mandiri, dewasa dan setia kawan (Indrianie, 2015). Walaupun para siswa belajar hanya dengan teman, hal tersebut tidak mengurangi pencapaian nilai afektif, siswa tetap belajar dengan penuh percaya diri, semangat, disiplin, jujur, dan penuh tanggung jawab. Lebih lanjut tutor sebaya ini juga dapat memperkuat hubungan antara sesama siswa (Izzati, 2015). Peningkatan hasil belajar siswa dapat dilihat dari tabeltabel yang telah disajikan, yaitu pada pratindakan siswa yang telah mencapai nilai KKM 18 anak (45\%) dan sisanya 22 anak belum mencapai nilai KKM. Pada siklus I siswa yang telah mencapai nilai KKM 20 anak (50\%) dan sisanya 20 anak belum mencapai nilai KKM. Pada siklus II siswa yang telah mencapai nilai KKM 32 anak $(82,87 \%)$ dan sisanya 8 anak belum mencapai nilai KKM. Dari pratindakan ke siklus I jika dibandingkan terlihat kenaikan hasil belajar siswa mengalami kenaikan 2 anak $(9 \%)$ dan dari siklus I ke siklus II mengalami kenaikan 12 anak (35\%). Melihat hasil penelitian yang sudah peneliti lakukan dan beberapa penelitian lain yang mendukung didapatkan informasi bahwa metode tutor sebaya dapat diterapkan pada anak di tingkat sedolah dassar maupun sekolah menengah pertama. Bahkan, Metode pada penelitian lain juga menunjukkan bahwa metode Tutor sebaya juga berhasil diterapkan pada tingkat sekolah menengah atas pada materi bola voli. Hal ini data dilihat pada penelitian (Noviyanto \& Hidayat,
2017). Penelitian tersebut menunjukkan bahwa ada pengaruh yang signifikan metode tutor sebaya terhadap hasil belajar passing bawah dan passing atas bolavoli.

\section{SIMPULAN}

Berdasarkan analisis data hasil belajar passing atas bola voli mini siswa kelas VC SD Negeri 83 Pekanbaru Tahun Pelajaran 2018/2019 dapat disimpulkan bahwa penerapan metode bantuan tutor sebaya dapat meningkatkan hasil belajar passing atas bola voli mini siswa kelas VC SD Negeri 83 Pekanbaru Tahun Pelajaran 2018/2019.

\section{DAFTAR PUSTAKA}

Allo, M. R., Sumarsono, A., \& Syamsudin. (2020). Meningkatkan Kemampuan Hasil Belajar Lempar Lembing Dengan Menggunakan Media Turbo. Musamus Journal of Physical Education and Sport (MJPES), 03(01), 1-13. https://doi.org/10.35724/mjpes.v

Dadi, S. (2020). Belajar passing atas bola voli melalui tutor teman sebaya pada siswa kelas v. Jurnal DIKDAS BANTARA, 3(1), 1-13.

Fadlih, A. M., \& Riyanto, P. (2019). Minat dan Motivasi Peserta Didik Penyandang Disabilitas Ketunarunguan terhadap Mata Pelajaran Pendidikan Jasmani Kesehatan dan Olahraga. Musamus Journal of Physical Education and Sport (MJPES), 2(01), 68-76. https://doi.org/10.35724/mjpes.v2i01.20 72 
Haris, I. N. (2018). Model pembelajaran peer teaching dalam pembelajaran pendidikan jasmani. Journal of Chemical Information and Modeling, 4(9), 2.

file://C:/Users/asus/Downloads/191Article Text-651-2-10-20180222.pdf

Hartanti, M. D., \& Hidayat, T. (2016). Hubungan antara tingkat konsentrasi siswa terhadap ketepatan service atas dalam permainan bolavoli (studi pada peserta ekstrakurikuler bolavolit smk negeri 1 surabaya ). Jurnal Pendidikan Olahraga Dan Kesehatan, 04(2), 288294.

Hendriawan, A. T., \& Indahwati, N. (2019). Pengaruh metode pembelajaran tutor sebaya terhadap hasil belajar passing atas bolavoli. Jurnal Pendidikan Olahraga Dan Kesehatan, 7(3), 143146.

Hidayat, A., \& Iskandar, D. (2019). Efektivitas Underhand Servis Posisi Lurus dan Posisi Menyamping Terhadap Akurasi Servis Bawah. JUARA: Jurnal Olahraga, 4(1), 62. https://doi.org/10.33222/juara.v4i1.452

Indrianie, N. S. (2015). Penerapan Model Tutor Sebaya Pada Mata Pelajaran Bahasa Inggris Reported Speech Terhadap Hasil Belajar Peserta Didik Man Kota Probolinggo. Jurnal Kebijakan Dan Pengembangan Pendidikan, $\quad 1(1), \quad 126$. http://ejournal.umm.ac.id/index.php/jm kpp/article/download/2210/2357

Izzati, N. (2015). Pengaruh Penerapan Program Remedial Dan Pengayaan Melalui Pembelajaran Tutor Sebaya Terhadap Hasil Belajar Matematika Siswa. Eduma : Mathematics Education Learning and Teaching, 4(1). https://doi.org/10.24235/eduma.v4i1.20

Maulina, Y. (2018). Meningkatkan hasil belajar passing atas bola voli mini melalui bantuan tutor sebaya siswa kelas V SD Negeri 5 Sabang. 2(1), 8593.

Nadhiroh, L., \& Hidayat, T. (2017). Pengaruh Metode Tutor Sebaya Terhadap Hasil Belajar Passing Atas Bolavoli. Jurnal Pendidikan Olahraga Dan Kesehatan, 05(03), 625-632.

Noviyanto, A., \& Hidayat, T. (2017). Pengaruh Penerapan Metode Pembelajaran Tutor Sebaya Terhadap Hasil Belajar Pasing Bawah Bolavoli Pada Siswa Kelas Xi Di Sma Negeri Plandaan Jombang. Jurnal Pendidikan Olahraga Dan Kesehatan, 4(3), 682689.

Patamani, H. (2018). Penerapan Metode Tutor Sebaya Dalam Meningkatkan Hasil Belajar Passing Atas Pada Permainan Bola Voli Mini. AKSARA Jurnal Ilmu Pendidikan Nonformal, 4(1), 35-40. http://ejurnal.pps.ung.ac.id/index.php/A KSARA/index 
Journal of Sport Education (JOPE), 3 (1) 2020 - 52

Yusuf Utama

Sugiyono. (2019). Metode Penelitian Kontribusi Kekuatan Otot Lengan

Pendidikan (Kuantitatif, Kualitatif, terhadap Keterampilan Smash dalam

Kombinasi, $R \& D$, dan Penelitian Permainan Bola Voli. Gelanggang

Pendidikan). ALFABETA. Olahraga: Jurnal Pendidikan Jasmani

Supriyanto, S., \& Martiani, M. (2019).

Dan Olahraga (JPJO), 3(1), 74-80.

https://doi.org/10.31539/jpjo.v3i1.829 